\title{
Усиление локальных электромагнитных полей оптическими периодическими резонаторами
}

\author{
А.К. Сарычев ${ }^{1, *}$, К.Н. Афанасьев ${ }^{1}$, И.В. Быков ${ }^{1}$, И.А. Богинская ${ }^{1}$, А.В. Иванов ${ }^{1}$, \\ И.Н. Курочкин ${ }^{2,3}$, А.Н. Лагарьков ${ }^{1}$, А.М. Мерзликин ${ }^{1}$, В.В. Михеев ${ }^{4}$, Д.В. Негров ${ }^{4}$, \\ И.А. Рыжиков ${ }^{1}$, М.В. Седова ${ }^{1}$ \\ ${ }^{1}$ Институт теоретической и прикладной электродинамики (ИТПЭ РАН) \\ ${ }^{2}$ Институт биохимической физики им. Н.М. Эмануэля (ИБХФ РАН) \\ ${ }^{3}$ Московский государственный университет им. М.В. Ломоносова, химический факультет (МГУ) \\ ${ }^{4}$ Московский физико-технический институт (МФТИ) \\ *E-mail: sarychev_andrey@yahoo.com
}

DOI:10.31868/RFL2018.21-22

Эффект гигантского комбинационного рассеяния (ГКР) света и связанное с ним усиление сигнала комбинационного рассеяния (КР) от молекул вещества является физической основой для разработки высокоэффективных биологических и химических сенсоров, способных регистрировать малые концентрации молекул, вплоть до единичных. Однако сам сигнал КР настолько слаб, что его почти невозможно наблюдать на фоне люминесценции и других оптических сигналов.

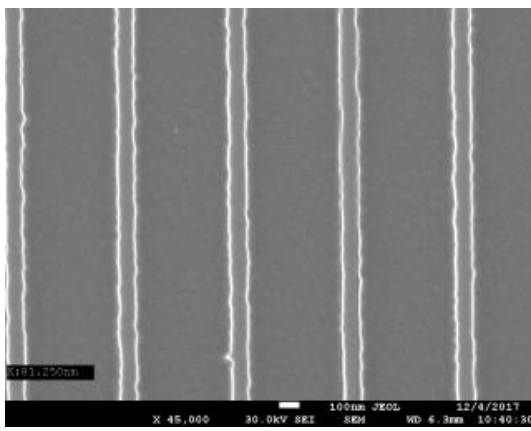

(a)

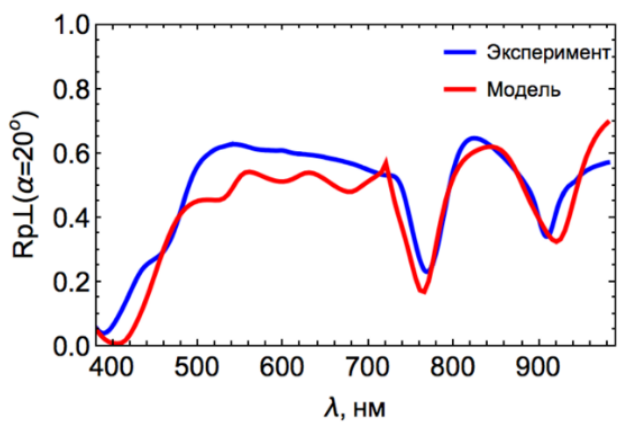

(б)

Рис.1 (a) Сканирующая электронная микроскопия (СЭМ). Периодическая система кремниевых гребней. Параметры: период 561 нм, высота 80 нм, поверхностный слой серебра составляет 20 нм. (б) Коэффициент отражения от структуры для угла падения $20^{\circ}$. Плоскость падения и вектор напряженности электрического поля перпендикулярны гребням.

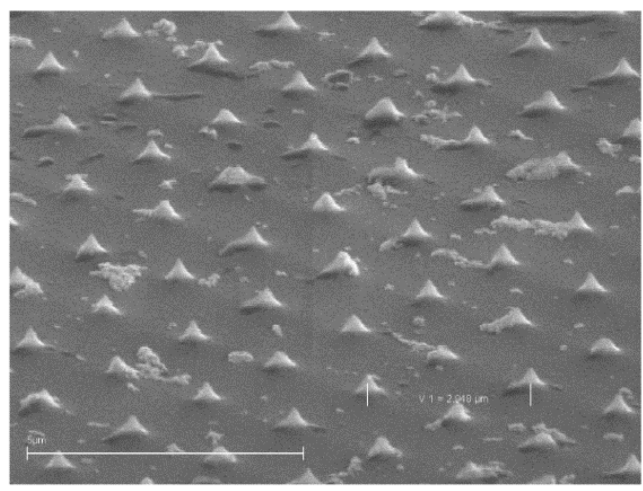

(a)

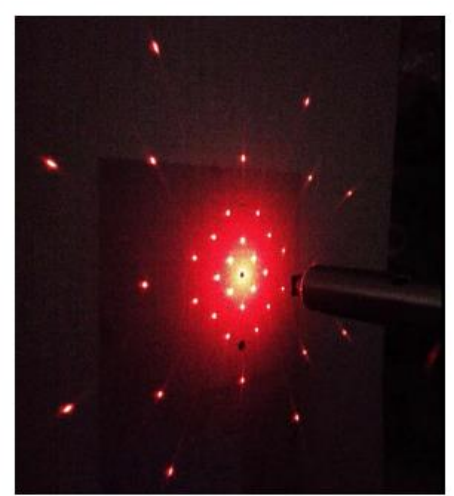

(б)

Рис.2 (a) Сканирующая электронная микроскопия (СЭМ). (б) Дифракционная картина оптического резонатора в виде пирамид. 
В работе предложен ряд кремниевых оптических резонаторов с периодически профилированной поверхностью с нанесенным нанослоем серебра (Рис. $1 \boldsymbol{a}, 2 \boldsymbol{a}$ ). Такие резонаторы позволяют существенно увеличить соотношение «полезный сигнал КР/шум» за счет использования высокодобротного оптического диэлектрика в виде кремния. Оптический резонатор в виде полос изготовлен из кремния Si (100) методом электронно-лучевой литографии (Crestec КАБЕ 9000С) с последующим плазмохимическим травлением кремния (CORIAL 200I) и напылением нанослоя серебра толщиной 20 нм.

Проведено компьютерное моделирование, подобран химический состав и геометрические параметры для генерации колоссальных локальных полей на поверхности резонаторов. Проведены работы по измерению коэффициента отражения и дифракции в таких структурах. Результаты расчетов и экспериментов продемонстрировали ярко выраженные металлодиэлектрические резонансы, зависящие от угла падения, и связанные с возбуждением поверхностных волн в резонаторе посредством дифракции падающего света (Рис. 1б,2б). Помимо плазмонных резонансов, определяемых периодом дифракционной решетки, в резонаторе, покрытом слоем серебра, возбуждаются и резонансы типа Фабри-Перо, локализованные в области выступов. Показано, что добротностью, а также положением таких резонансов можно управлять, изменяя режим напыления серебра на поверхность метаматериала. Проведены экспериментальные работы по регистрации сигнала комбинационного рассеяния (КР) света от модельного аналита - 5.5-дитио-бис(2-нитробензойной кислоты) (ДТНБ). Результаты продемонстрировали аномальную дифракцию (Рис. 2б) и относительное усиление сигнала КР от ДТНБ на характерных стоксовых частотах в структурированных областях - на несколько порядков величины. Подход, предложенный в работе, который заключается в создании регулярно профилированных металлодиэлектрических резонаторных структур, представляет практический интерес для разработки новых биосенсорных систем $[1,2]$.

Работа выполнена при поддержке грантов РФФИ № 17-08-01448, № 18-58-00048, и программ Президиума РАН № 40 «Создание сверхчувствительных методов идентификации биологических объектов с помощью оптических метаматериалов» и № 56 «Фундаментальные основы прорывных технологий в интересах национальной безопасности».

\section{Литература}

[1] A.K. Sarychev, A. Lagarkov et al, Proc. of SPIE 10346, 103460 (2017)

[2] A. Lagarkov, I. Boginskaya et al, Opt. Express 25 (15), 17021-17038 (2017) 